\title{
Perbedaan Hasil Pemeriksaan Sputum Basil Tahan Asam Antara PasienTuberkulosis Yang Perokok Dan Bukan Perokok Di Balai Pengobatan Penyakit Paru Lubuk Alung
}

\author{
Nurul Ziqra ${ }^{1}$, Elizabeth Bahar ${ }^{2}$, Edison $^{3}$
}

\begin{abstract}
Abstrak
Merokok dan Tuberkulosis (TB) merupakan dua masalah kesehatan di dunia walaupun TB lebih banyak ditemukan di negara berkembang. Kebiasaan merokok dan tuberkulosis memiliki hubungan yang erat. Tujuan penelitian ini adalah mmenentukan perbedaan hasil pemeriksaan sputum basil tahan asam antara pasien yang perokok dan bukan perokok di Balai Pengobatan Penyakit Paru (BP4) Lubuk Alung. Penelitian ini menggunakan desain cross sectional komparatif terhadap 44 penderita TB perokok dan 44 penderita TB non perokok yang dipilih secara consecutive sampling. Data dikumpulkan dari hasil pemeriksaan di Laboratorium dan wawancara. Hasilnya dianalisis dengan uji chi-square. Berdasarkan uji statistik didapatkan perbedaan yang bermakna antara penderita TB paru perokok dan non perokok berdasarkan hasil pemeriksaan BTA $(p=0,023)$. Kesimpulan studu ini ialah pasien TB banyak ditemukan pada usia produktif dan pada jenis kelamin laki-laki. Pada perokok lebih banyak ditemukan BTA positif daripada bukan perokok.
\end{abstract}

Kata kunci: tuberkulosis paru, BTA, perokok

\section{Abstract}

Smoking and Tuberculosis (TB) are two major health problems in the world even though TB is more common in developing countries. Smoking habit and tuberculosis have a close relationship. The objective of this study was to determine the differences in the results of Sputum Basil Tahan Asam examination between smokers and nonsmokers tuberculosis patients in the Lubuk Alung Pulmonary Disease Treatment Center. The desain of this study was a comparative cross-sectional on 44 TB smoker patients and 44 TB non-smoker patients by consecutive sampling. Data were collected through checkup in the laboratory and the interviews with new patients. The results were analyzed with the chi-square test.The statistic result showed significant differences between patients with pulmonary tuberculosis smokers and non-smokers based on the results of BTA checks ( $p$ value: 0.023). The conclusions was TB patients are found in the productive age and the male gender. Acid fast bacilli positive in smoker is higher than non-smokers.

Keywords: pulmonary tuberculosis, acid fast bacilli, smoker

Affiliasi penulis: 1. Prodi Profesi Dokter FK UNAND (Fakultas Kedokteran Universitas Andalas Padang),, 2. Bagian Mikrobiologi FK UNAND, 3. Bagian Kesehatan Masyarakat FK UNAND

Korespondensi: Nurul Ziqra, Email :nurul.ziqra@yahoo.co.id Telp: 083180499455

\section{PENDAHULUAN}

Merokok dan tuberkulosis (TB) merupakan dua masalah besar kesehatan di dunia setelah HIV dan

AIDS meluas, TB menjadi penyebab kematian yang terkemuka di seluruh dunia dan bertanggung jawab terhadap lebih dari satu juta kematian setiap tahun. ${ }^{1}$

Tembakau khususnya kebiasaan merokok secara luas telah diakui menimbulkan masalah kesehatan masyarakat seperti kanker paru, penyakit kardiovaskuler yang memperburuk keadaan penderita TB. ${ }^{1}$ Penyakit TB adalah penyakit yang disebabkan oleh Mycobacterium tuberculosis complex dan merupakan salah satu masalah kesehatan masyarakat yang penting di Indonesia. ${ }^{2}$ 
Tahun 2011 ditemukan sekitar 8, 7 milyar kasus TB baru di dunia dan sekitar 1, 4 milyar orang meninggal karena TB. ${ }^{3}$ Lima dari dua puluh dua negara dengan beban penyakit TB yang tertinggi di dunia berada di kawasan Asia Tenggara dan sekitar $35 \%$ kasus TB berasal dari Indonesia. ${ }^{4}$ Berdasarkan survei kesehatan nasional 2001, TB menempati peringkat ketiga sebagai penyebab kematian tertinggi di Indonesia. ${ }^{5}$ Pada tahun 2011, Indonesia termasuk dalam lima besar negara dengan angka kejadian TB tertinggi di dunia. ${ }^{6}$ Menurut data Kemenkes RI (2012), pada tahun 2011 ditemukan sekitar 6691 kasus TB di Sumatera Barat atau sekitar 57,6 \%. ${ }^{4}$

Indonesia juga termasuk dalam "high burden countries" di bidang rokok bersama dengan 4 negara yaitu Cina, India, Rusia dan Bangladesh. Negara Indonesia menduduki peringkat kelima dalam konsumsi rokok dunia serta peringkat ketujuh dalam penghasil tembakau. ${ }^{7}$ Merokok dan tuberkulosis memiliki hubungan yang erat. ${ }^{8}$ Penelitian Aditama (2009) menunjukan perokok lebih sering mendapat TB dan kebiasaan merokok memegang peranan penting sebagai faktor penyebab kematian TB. ${ }^{9}$ Penelitian Matsumoto di Jepang juga menunjukan bahwa pada perokok derajat kepositifan BTA (Basil Tahan Asam) dari pemeriksaan sputumnya lebih tinggi dibandingkan bukan perokok. ${ }^{10}$ Pada perokok ditemukan hasil pemeriksaan BTA positif lebih tinggi. ${ }^{11}$

Hal ini disebabkan oleh Kebiasaan merokok akan merusak mekanisme pertahanan paru yang disebut muccociliary clearance. Merokok juga menyebabkan terganggunya pertahanan alamiah paru yang dimediasi oleh makrofag, sel epitel, sel dendritik dan sel natural killer sehingga meningkatkan risiko, keparahan dan durasi infeksi. ${ }^{1}$

Merokok terbukti dapat mengganggu bersihan mukosilier. Pada perokok terjadi penurunan respon kekebalan tubuh, gangguan mekanik fungsi silia, cacat pada respon imun makrofag sehingga meningkatkan kerentanan terhadap TB paru serta dapat menurunkan aktivitas lisosim A yang mempunyai sifat bakterisidal dan mekanisme hidrolisis bagian polisakarida dari dinding sel bakteri TB. ${ }^{2}$

Balai Pengobatan Penyakit Paru (BP4) dipilih sebagai tempat pengambilan data penelitian karena BP4 dibentuk sebagai upaya untuk lebih mendekatkan dan memberikan pelayanan spesialistik khusus paru ke masyarakat maupun untuk mengatasi berbagai permasalahan kesehatan paru di masyarakat. Untuk melaksanakan tugas tersebut maka BP4 menjalankan fungsi sebagai penetapan diagnosis penyakit paru, pengobatan penderita penyakit paru, perawatan penderita penyakit paru, membantu usaha pemberantasan penyakit TB dan melaksanakan system rujukan. $^{2}$

Berdasarkan data rekam medis, TB merupakan salah satu dari lima besar penyakit terbanyak di BP4 Lubuk Alung. BP4 Lubuk Alung juga merupakan balai pengobatan yang mencanangkan gerakan stop merokok pada masyarakat. Tujuan penelitian ini adalah untuk menentukan perbedaan hasil pemeriksaan sputum BTA antara pasien TB yang perokok dan bukan perokok di BP4 Lubuk Alung.

\section{METODE}

Dengan desain cross sectional, populasi penelitian adalah semua pasien yang datang ke balai pengobatan penyakit paru Lubuk Alung yang didiagnosis tuberculosis pada periode April-Juni 2014, berjumlah 44 orang yang diambil dengan cara consecutive sampling. Kriteria inklusi adalah pasien Tuberkulosis Paru yang berobat ke Balai Pengobatan Penyakit Paru Lubuk Alung yang bersedia diwawancarai dengan umur lebih atau sama 15 tahun. Untuk variabel dependen dalam penelitian ini adalah hasil pemeriksaan BTA. Langkah-langkah pengolahan data adalah pemeriksaan kelengkapan dan kejelasan data, pemberian kode pada setiap data variabel, memasukkan data dalam program SPSS (Statistical Program for Social Science), serta pemeriksaan kembali untuk memastikan bahwa data tersebut telah bersih dari kesalahan. Untuk analisis data terdiri dari analisis univariat dan bivariat. Pada analisis bivariat dicari hubungan antara dua variabel.

HASIL

Karakteristik Responden

Tabel 1. Karakteristik responden menurut jenis kelamin dan umur

Karakteristik $\quad$ Frekuensi (\%) 
Jenis Kelamin

Laki-laki

Perempuan

Usia

Usia $<20$ tahun

Usia 21-40 tahun

Usia 41-60 tahun

Usia $>60$ tahun

Indeks brinkman

Tidak merokok

Ringan

Sedang

Berat

Pada Tabel 1 dapat dilihat bahwa dari 88 pasien TB yang diteliti sebagian besar merupakan jenis kelamin laki-laki sebanyak 54 orang dan wanita 34 orang. Distribusi umur paling banyak berada pada usia 41-60 tahun 38 orang. Hasil pemeriksaan BTA pada pasien TB didapatkan paling banyak BTA positif 3 sebanyak 33 orang.

Tabel 2. Hasil pemeriksaan BTA responden

\begin{tabular}{cc}
\hline Hasil Pemeriksaan BTA & Frekuensi (\%) \\
\hline Negatif & $23(26,1 \%)$ \\
Positif 1 & $16(18,2 \%)$ \\
Positif 2 & $16(18,2 \%)$ \\
Positif 3 & $33(37,5 \%)$ \\
Total & $88(100 \%)$ \\
\hline
\end{tabular}

Berdasarkan Tabel 2 dapat diketahui bahwa pada persentase hasil pemeriksaan BTA positif 3 lebih tinggi pada perokok (40,4\%) dibandingkan dengan yang bukan perokok (34, 1\%). Dari hasil uji statistik dengan chi-square didapatkan $\mathrm{p}=0,023$ sehingga dari analisis statistik disimpulkan terdapat perbedaan yang bermakna antara penderita TB paru perokok dan non perokok berdasarkan hasil pemeriksaan BTA.

\section{PEMBAHASAN}

Berdasarkan hasil penelitian, penderita TB perokok lebih banyak pada jenis kelamin laki-laki 61 ,

$4 \%$ dibandingkan perempuan 38,6\%. Usia terbanyak penderita TB paru berada pada usia 41-60 tahun 43, $2 \%$. Dalam buku ilmu penyakit dalam dikatakan bahwa secara epidemiologi penderita TB paling banyak pada usia produktif. Tingginya angka penderita TB pada usia produktif, karena pada usia tersebut masyarakat sering berinteraksi dengan lingkungan baik untuk mencari nafkah maupun menuntut ilmu, sehingga memungkinkan terjadinya penularan yang lebih luas dari lingkungan. ${ }^{5}$

Berdasarkan hasil pemeriksaan BTA, pada penderita TB perokok didapatkan hasil pemeriksaaan terbanyak adalah BTA positif 3 sebanyak 40,9\%, Sedangkan, pada penderita TB non perokok didapatkan hasil pemeriksaan terbanyak adalah BTA negatif sebanyak 38, 6\%. Hasil uji statistik dengan chisquare didapatkan $\mathrm{p}=0,023(\mathrm{p}<0,05)$ sehingga dari analisis statistickdisimpulkan terdapat perbedaan yang bermakna antara penderita TB paru perokok dan non perokok berdasarkan hasil pemeriksaan BTA. ${ }^{8}$

Secara biologis hubungan merokok dengan peningkatan risiko TB adalah melalui penurunan respons kekebalan tubuh, gangguan mekanik fungsi silia, cacat pada respons imun makrofag sehingga meningkatkan kerentanan terhadap TB paru serta dapat menurunkan aktivitas lisosim A. Merokok juga akan memperburuk TB dengan merusak mekanisme pertahanan paru, silia yang telah rusak tidak mudah membuang infeksi yang sudah masuk di paru. Hilangnya pertahanan mukosa dapat mengakibatkan kolonisasi bakteri, rokok juga mengganggu mekanisme pertahanan alamiah yang dimediasi oleh makrofag, sel epitel, sel dendritik (DCs) dan sel natural killer (NK) sehingga meningkatkan risiko, keparahan dan durasi infeksi. ${ }^{1}$

\section{KESIMPULAN}

Terdapat perbedaan yang bermakna antara pasien TB paru perokok dan non perokok berdasarkan hasil pemeriksaan BTA, dengan hasil pemeriksaan BTA positif lebih tinggi pada kelompok perokok.

\section{DAFTAR PUSTAKA}

1. Wijaya AA. Merokok dan tuberkulosis. Jurnal Tuberkulosis Indonesia. 2012;8 (diunduh 25 Januari 2014). Tersedia dari: URL: HYPERLINK http://ppti.info/ArsipPPTI/PPTI-Jurnal-Maret-

2012.pdf

2. PDPI. Pedoman diagnosis dan penatalaksanaan penyakit paru obstruksi kronis (PPOK) di Indonesia. 2010 (diunduh 20 Februari 2014). 
Tersedia dari: URL: HYPERLINK http://www. klikpdpi.com

3. WHO. Tuberculosis control in the Shout East Asia Region. 2012 (diunduh 13 Februari 2014).Tersedia dari: URL: HYPERLINK http://www.searo.who.int.

4. Kementerian Kesehatan Republik Indonesia, Strategi nasional pengendalian TB dilndonesia 2010-2014. 2011 (diunduh 14 Februari 2014). Tersedia dari: URL: HYPERLINK http://www. depkes.go.id/ asset/ regulasi/STRANAS TB.pdf

5. Amin Z, Bahar A. Buku ajar ilmu penyakit dalam Jilid III. Edisi ke-5. Jakarta: Internal Publishing; 2009. hlm. 2230-9.

6. Kementerian Kesehatan Republik Indonesia. Profil data kesehatan Indonesia tahun 2011. serial online 2012 (diunduh 10 Januari 2014). Tersedia dari: URL: HYPERLINK http://www.depkes.go.id

7. Aditama TY. Tuberkulosis, rokok dan perempuan. Jakarta : Balai Penerbit FKUI. 2006.
8. Schluger NW. The deadly pairing of tuberculosis and smoking. World Lung Foundation Directions. 2011;2(2):(diunduh 22 Juli 2013). Tersedia dari: URL: HYPERLINK http://www.worldlungfoundation. org/ht/a/GetDocumentAction/i/15317

9. Aditama TY. Youth tobacco Indonesian eksperience. Mumbai, India: Indonesian Smoking Control Foundation. 2009.

10. Matsumoto $\mathrm{K}$, et al. The association between smoking and sputum smear positive pulmonary tuberculosis in Osaka City. 2012 (Diunduh 26 Februari 2014). Tersedia dari: URL: HYPERLINK http://www.ncbi.nlm.nih.gov.

11. WHO. TB and tobacco control. 2007 (diunduh 22 Januari 2014). Tersedia dari: URL: HYPERLINK http://www.who.int. 